\title{
Microbiological quality determination of pasteurized, UHT and flavoured milk sold in Dhaka, Bangladesh
}

\author{
Jubaida Binte Jamal, Sharmin Akter and Md. Aftab Uddin* \\ Department of Microbiology, Stamford University Bangladesh, 51, Siddeswari Road, Dhaka 1217, Bangladesh
}

Received 05 February 2018/Accepted 24 March 2018

\begin{abstract}
The present study was undertaken to determine the microbiological quality of pasteurized milk, UHT milk and flavoured milk samples collected from different locations in Dhaka, Bangladesh. Twenty pasteurized milk samples, fifteen UHT milk samples and fifteen flavoured milk samples of different brand were collected and different batch were analyzed for enumerating the total viable bacterial count (TVBC), total coliform count (TCC) and physiochemical tests (sensory test, alcohol test, acidity test, fat test, CLR test, SNF). The range of TVBC and pasteurized milk samples was between $2.3 \times 10^{2}$ $\mathrm{cfu} / \mathrm{ml}$ to $4.69 \times 10^{3} \mathrm{cfu} / \mathrm{ml}$. TVBC range of flavoured milk samples was between $5.0 \times 10^{1} \mathrm{cfu} / \mathrm{ml}$ to $1.8 \times 10^{2}$ and no TVBC was detected for any of the UHT milk samples. No TVBC was found for flavoured milk samples of company-8 (UHT). Because it was processed with ultra high temperature, slightly lower than that recommended by BSTI (not exceeding $20,000 \mathrm{cfu} / \mathrm{ml}$ ). Coliform bacteria were present only for pasteurized milk samples in one brand, though the count was under acceptable range according to BSTI recommendation $(<10 / \mathrm{ml}$ coliform in pasteurized milk). Physiochemical tests are also very important to detect the quality of milk samples. Acidity range should not exceed 0.14, for this study fat range should be minimum $3.5 \%$ and SNF should be minimum $8 \%$. In this study, for pasteurized milk samples acidity range was between 0.14-0.16, fat range was between 3.5-3.9\% and SNF was between the ranges of 8-9.784\%. For UHT milk samples acidity range was between 0.13-0.16, fat range was between 3.5-3.8\% and SNF was between 8.034-9.012. All the results of sensory and physiochemical tests for pasteurized and UHT milk samples were satisfactory. So, UHT processed milk and flavoured milk can be considered as safe for consumption within the mentioned expiry date without heat treatment.
\end{abstract}

Keywords: Pasteurized milk; UHT milk, Flavoured milk, Microbiological quality

Milk is one of the most absolute natural food found in world (1). Milk is a beneficial and healthy drink which can be consumed on daily basis. Milk contains fat, protein, carbohydrates, minerals, vitamins and other various ingredients disseminated in water that makes it a complete diet (2). On the other hand flavoured milk made with milk, sugar, colorings and artificial or natural flavorings. Flavored milk is often pasteurized using ultra-high-temperature (UHT) treatment or pasteurization process which gives it a longer shelf-life than plain milk. Pre-mixed flavored milk is sold in the refrigerated dairy case alongside other milk products (3). But at the same time, it is highly vulnerable to bacterial contamination and hence is easily delicate (4).

The chemical character of milk is such that it has high moisture, $\mathrm{pH}$ measures nearly neutral and they are also rich in vitamins. These surroundings create a positive atmosphere for the pathogens to survive, grow and reproduce even though they are pasteurized or refrigerated.

While secreting from the udder of healthy animal, milk hardly contains any bacteria. Accordingly the

*Corresponding Author: Mailing address. Aftab Uddin, Assistant Professor, Department of Microbiology, Stamford University Bangladesh, 51 Siddeswari Road, Dhaka 1217, Bangladesh, Bangladesh; E-mail: aftab_mb12@yahoo.com. exterior of the udder and the adjacent areas, machines used for milking purpose, milking man himself may take part in the contamination process, if his hands are not washed properly, or due to use of insanitary dairy utensils. These things may all supply the entry of bacteria, yeast and molds in the milk. Thus milk and milk products made from the spoiled milk become an important source of food borne pathogens. Besides some microorganisms are used in the preparation and preservation of milk products like yogurt and cheese (5).

In Bangladesh, milk is collected mostly in nonstandardized way and is usually supplied to the consumers from the urban and rural areas by milkmen (6). The adulteration in milk causes change in the amount of components in milk as well as the introduction of various pathogens in the milk. So it is very much important to treat the milk in such a way so that it ensures the safety as well as continue the clarity of the milk quality (7). The introduction of pasteurized as well as UHT milk in Bangladesh is not new and proved to be very well accepted among consumers. At present microbiological status of different processed milk is gaining attention. High microbial load in milk is unpredictable in the pasteurized or UHT treated milk. The suggested date of expiry for the pasteurized and the 
UHT milk is 7 days and 6 months respectively after the date of production. But milk quality may be deteriorated before expiry date due to the poor preliminary milk quality, faulty dispensation or problem in preservation at the consumer side (6). The Bangladesh Standards and Testing Institution (BSTI) oblige various chemical and sanitary requirements for the pasteurized milk (8).

Milk is an ideal food for all age groups of both rural and urban people in Bangladesh. But milk can also serve as a potential vehicle for transmission of some diseases under certain circumstances. Milk is also an admirable resource and defensive medium for certain microorganisms, which may include impending pathogens capable of causing a variety of health problems to the consumers (9). To reduce the diseases transmitted by raw and processed milk upon consumption, regular microbiological analysis is necessary to carry out.

Current study reveals the microbiological quality of pasteurized milk, UHT milk samples and flavoured milk of different brand and different batch collected from different areas in Dhaka, Bangladesh. The findings of the study will be an indication about the total aerobic plate count, total coliform count (TCC) to determine the overall microbial load from different Pasteurized, UHT and flavored milk samples as well as the detection of physiochemical properties of all the milk samples like Alcohol test, fat test, CLR, SNF, $\mathrm{pH}$, Acidity, methylene blue dye, reduction test.

\section{MATERIALS AND METHODS}

Sample Collection. Total 50 pasteurized, UHT processed milk and the flavoured milk (Mango milk and chocolate milk) samples of different brand and different batch were collected from different markets around Dhaka city (10).

Sample processing. For pasteurized milk $1 \mathrm{ml}$ of the milk sample was taken into $9 \mathrm{ml}$ normal saline which gives $10^{-1}$ dilution. Vortex machine was used to homogenize the sample. Serial dilutions of samples were made up to $10^{-2}$ in sterile normal saline. For UHT direct $1 \mathrm{ml}$ sample was taken (10).

Enumeration of total viable bacterial count (TVBC) and total coliform count (TCC) by pour plate method. One $\mathrm{ml}$ of the sample was transferred to the petri dish and covered immediately with the lid followed by pouring $18-20$ $\mathrm{ml}$ of sterile agar culture medium. The inoculums and medium were then mixed by clockwise and anti-clock wise rotation. The agar was allowed to solidify completely and the plates are incubated at $37{ }^{\circ} \mathrm{C}$ for 24 hours for TCC and 48 hours for TBC. After incubation period, both surface and sub-surface colonies were observed. The plates were screened for the presence of discrete colonies after incubation period and the actual numbers of bacteria were estimated as colony forming unit in per $\mathrm{ml}(\mathrm{cfu} / \mathrm{ml})$. All the results were between ranges according to BDS standard (11)

Physiochemical tests

Alcohol test. One $\mathrm{ml}$ milk sample was taken in a test tube after that $1 \mathrm{ml} 75 \%$ ethyl alcohol was added and shakes. If milk is not colt then milk is alcohol +ve (Accepted) and if milk becomes clot milk is alcohol -ve (Rejected) (12).

pH test. Hundred $\mathrm{ml}$ milk was taken in a beaker then $\mathrm{pH}$ was checked by using digital $\mathrm{P}_{\mathrm{H}}$ meter. Proper $\mathrm{pH}$ range is between 6.6-6.8 (13).

Acidity test. First, $9 \mathrm{ml}$ milk sample was taken with $1 \mathrm{ml}$ of Phenolphthalein in a beaker. After that Titration was done against $0.1 \mathrm{~N} \mathrm{NaOH}$ until pink colour. Accepted acidity range is $0.14-0.16 \%$ (13).

Fat test. Ten $\mathrm{mL}$ 90\% sulphuric acid was taken in a butyrometer and $10 \mathrm{ml}$ milk sample was added by making a different layer. After that $1 \mathrm{ml}$ amyal alcohol was added and vigorous shaking was done. Centrifugation was done by using centrifuge machine for 5 minutes. 0 or digit position was adjusted of butyrometer \& reading was taken for lower minicus position it shows fat $\%$.
BDS recommended fat range raw milk is between 3.5-6\% and for pasteurized milk and UHT milk minimum fat range in $3.5 \%$ (14)

Corrected Lactometer Reading (CLR) test. For CLR test milk sample should be at $20{ }^{\circ} \mathrm{C}$. $250 \mathrm{ml}$ milk sample was taken in measuring cylinder and then lactometer was immersed in milk. If the temperature of milk sample is below $20^{\circ} \mathrm{C}$ then the calculation will be: Lactometer reading-(temperature difference) $\times 0.2$ and if the temperature of the sample milk is above $20{ }^{\circ} \mathrm{C}$ then the calculation will be: Lactometer reading + (temperature difference) $\times 0.2(15)$.

SNF (Calculation method). This calculation is essential to detect Solids non fats $(\mathrm{SNF}) \%$ in milk sample SNF $=$ Fat $\times 0.22+\mathrm{CLR} \times 0.25+0.72(15)$.

Methylene Blue Dye Reduction Test for Assessing the Milk Quality. Methylene Blue Dye Reduction Test, regularly recognized as MBRT test is used as a speedy process to evaluate the microbiological quality of raw and pasteurized milk (16). $1 \mathrm{ml}$ methylene blue was taken tin a sterile test tube after that $9 \mathrm{ml}$ of milk sample was added and vigorous shaking was done. Incubation was done at 37 ${ }^{\circ} \mathrm{C}$. Tubes were checked for decolorization just after 10 minutes, 30 minutes and subsequently after every hour $(17,18)$.

\section{RESULTS AND DISCUSSION}

Milk is an ideal food for human health. Adulteration of milk reduces the quality of milk itself and the dairy products as well (8). The collected pasteurized milk, UHT milk and flavoured milk samples were analyzed for total viable bacterial count, total coliform count and the physiochemical properties. These findings may be helpful for the concerned governmental regulatory bodies to monitor the quality of the commercial milk products in the market.

Total Viable Bacterial Count (TVBC). The total viable bacterial count is the number of bacteria in a sample that can grow and form countable colonies on Plate count agar after being held at $35 \pm 2{ }^{\circ} \mathrm{C}$ for 48 hours. The results of bacterial allotment for pasteurized milk samples are obtainable in table 1. All the pasteurized milk had elevated bacterial load from the range of $2.3 \times 10^{2}$ $\mathrm{cfu} / \mathrm{ml}$ to $4.7 \times 10^{3} \mathrm{cfu} / \mathrm{ml}$. The results of bacterial distribution for UHT milk samples and all the samples showed very satisfactory results with no bacterial count (Table 2). The bacterial distribution results of flavored milk samples are presented in table 3. The UHT flavored milk showed no coliform count but the total bacterial load from the range of $5.0 \times 10^{1} \mathrm{cfu} / \mathrm{ml}$ to $1.8 \times 10^{2} \mathrm{cfu} / \mathrm{ml}$. All these results were between the range of BSTI (Bangladesh Standards and testing institution). BDS approved range of total bacterial load for pasteurized milk is $<20000 / \mathrm{ml}$ and for UHT milk is $<10 / 0.1 \mathrm{ml}(6)$.

For Company-1 samples the total bacterial count was ranging from $3.8 \times 10^{3} \mathrm{cfu} / \mathrm{ml}$ to $4.7 \times 10^{3} \mathrm{cfu} / \mathrm{ml}$. For samples of company-2 the bacterial load was ranging from of $2.3 \times 10^{2} \mathrm{cfu} / \mathrm{ml}$ to $4.7 \times 10^{3} \mathrm{cfu} / \mathrm{ml}$. For Company-3 samples, total bacterial count was between $2.1 \times 10^{3} \mathrm{cfu} / \mathrm{ml}$ to $3.9 \times 10^{3} \mathrm{cfu} / \mathrm{ml}$. The total bacterial range for company4 samples was between $5.6 \times 10^{2} \mathrm{cfu} / \mathrm{ml}$ to $6.3 \times 10^{2} \mathrm{cfu} / \mathrm{ml}$. All the results were proper according fo the BDS standards. (8). The TVBC (total viable bacterial count) of the pasteurized milk samples ranged from $2.3 \times 10^{2} \mathrm{cfu} / \mathrm{ml}$ to $4.69 \times 10^{3} \mathrm{cfu} / \mathrm{ml}$ (Table 1), a little inferior than that suggested by BSTI and USPHS. In an another study by 
TABLE 1. Microbiological quality analysis of pasteurized milk samples

\begin{tabular}{cccc}
\hline Brand name & $\begin{array}{c}\text { Serial } \\
\text { number }\end{array}$ & $\begin{array}{c}\text { Total viable bacterial count } \\
\text { (cfu/ml) }\end{array}$ & $\begin{array}{c}\text { Total coliform count } \\
\text { (cfu/ml) }\end{array}$ \\
\hline \multirow{3}{*}{ Company-1 } & 1 & $4.7 \times 10^{3}$ & Absent \\
& 2 & $3.9 \times 10^{3}$ & Absent \\
& 3 & $4.2 \times 10^{3}$ & Absent \\
& 4 & $4.6 \times 10^{3}$ & Absent \\
Company-2 & 5 & $3.8 \times 10^{3}$ & Absent \\
\hline & 1 & $4.2 \times 10^{2}$ & Absent \\
& 2 & $4.9 \times 10^{2}$ & Absent \\
& 3 & $2.3 \times 10^{2}$ & Absent \\
Company-3 & 4 & $3.98 \times 10^{2}$ & Absent \\
& 5 & $4.71 \times 10^{2}$ & Absent \\
\hline & 1 & $3.64 \times 10^{3}$ & $<10$ \\
& 2 & $3.32 \times 10^{3}$ & Absent \\
& 3 & $2.12 \times 10^{3}$ & $<10$ \\
Company-4 & 4 & $3.89 \times 10^{3}$ & $<10$ \\
& 5 & $3.86 \times 10^{3}$ & Absent \\
\hline & 1 & $6.25 \times 10^{2}$ & Absent \\
& 2 & $6.21 \times 10^{2}$ & Absent \\
& 3 & $5.59 \times 10^{2}$ & Absent \\
& 4 & $5.72 \times 10^{2}$ & Absent \\
& 5 & $6.11 \times 10^{2}$ & Absent \\
\hline
\end{tabular}

TABLE 2. Microbiological quality analysis of UHT milk samples

\begin{tabular}{cccc}
\hline Brand name & $\begin{array}{c}\text { Serial } \\
\text { number }\end{array}$ & $\begin{array}{c}\text { Total viable bacterial count } \\
\text { (cfu/ml) }\end{array}$ & $\begin{array}{c}\text { Total coliform count } \\
\text { (cfu/ml) }\end{array}$ \\
\hline & 1 & Nil & Absent \\
& 2 & Absent & Absent \\
Company-5 & 3 & Nil & Absent \\
& 4 & Nil & Absent \\
\hline & 5 & Nil & Absent \\
Company-6 & 1 & Nil & Absent \\
& 2 & Nil & Absent \\
& 3 & Nil & Absent \\
& 4 & Nill & Absent \\
\hline & 5 & Nill & Absent \\
& 1 & Nil & Absent \\
& 2 & Nil & Absent \\
& 3 & Nil & Absent \\
& 4 & Nil & Absent \\
\hline
\end{tabular}

TABLE 3. Microbiological quality of flavoured milk samples

\begin{tabular}{cccc}
\hline Flavoured milk brand & $\begin{array}{c}\text { Serial } \\
\text { number }\end{array}$ & $\begin{array}{c}\text { Total viable bacterial count } \\
\text { (cfu/ml) }\end{array}$ & $\begin{array}{c}\text { Total coliform count } \\
\text { (cfu/ml) }\end{array}$ \\
\hline & 1 & Nil & Absent \\
Company-8 (UHT) & 2 & Nil & Absent \\
& 3 & Nil & Absent \\
& 4 & Nil & Absent \\
& 5 & Nil & Absent \\
\hline & 1 & $1.0 \times 10^{2}$ & Absent \\
Comany-9 (pasteurized & 2 & $5.0 \times 10^{1}$ & Absent \\
mango milk) & 4 & $1.8 \times 10^{2}$ & Absent \\
& 5 & $6.0 \times 10^{1}$ & Absent \\
& 1 & $1.2 \times 10^{2}$ & Absent \\
\hline & 2 & $7.0 \times 10^{1}$ & Absent \\
Company-10 (pasteurized & 3 & $1.0 \times 10^{2}$ & Absent \\
Chocolate milk) & 4 & $1.8 \times 10^{2}$ & Absent \\
& 5 & $9.0 \times 10^{1}$ & Absent \\
\hline
\end{tabular}


Shojaei et al. (19) showed that the range of TVBC was between $6.7 \times 10^{4}$ to $7.5 \times 10^{4} \mathrm{cfu} / \mathrm{ml}$. The reason of high bacterial count in some of the pasteurized milks may include defective pasteurization machinery, surviving pasteurization, and post-pasteurized contamination due to poor processing and handling conditions and/or poor hygienic practices by workers.

On the other hand, TBC of each of the UHTprocessed milks were nil (Table 3). According to the description of UHT process, UHT milk should surround very little or no vigorous bacteria (11). No TBC were found for flavoured milk samples of company-8 (UHT). On the other hand TVBC range of pasteurized flavoured milk samples was from $5.0 \times 10^{1} \mathrm{cfu} / \mathrm{ml}$ to $1.8 \times 10^{2}$ are presented in table 3 . The results are accepted according to BDS standards.

Bacterial absence might be due to no problem in UHT process. The presence of bacteria in UHT milk might be due to many factors including the milk quality, process plant sanitation, status of packaging material and also the handling process (11). So the absence of bacterial contamination in UHT milk reveals the fact that the milk company produced high quality of UHT milk.

Total Coliform Count The presence of coliform bacteria Escherichia coli, in milk is an indication of fecal contamination. Only three samples of company-3 were found to be contaminated with coliform bacteria. The range of coliform was between 2-3/ml (not exceeding $<10 \mathrm{cfu} / \mathrm{ml})(8)$. Though the count is under range but as we know that presence of coliform bacteria indicate fecal contamination making the quality of company-3 samples not satisfactory. In a study by Uddin et al, 2011 (9), a numbers of total coliform was detected from pasteurized milk. Pasteurized milk should not contain any coliform bacteria as coliform bacteria cannot survive the pasteurization temperature but the presence of TCC of the pasteurized milk samples indicates either defect in pasteurization process or post pasteurization contamination which includes contamination in packaging materials, defects in pipe lines. On the other hand no coliform was present for any UHT milk samples and flavoured milk samples are presented in table 2 and table 3 . In this study, as not expected that the TCC was found in the different samples of company-3. For other pasteurized milk samples and flavoured milk samples the TCC was not present as this result was expected.

Physiochemical test results. Different types of physiochemical tests are used to detect the quality of milk samples such as acidity test, CLR test, fat test, $\mathrm{P}_{\mathrm{H}}$ test, alcohol test, SNF etc. as well as some sensory tests like color, flavour and test analysis (20). The results of our current samples under investigation have been given in table 4 and table 5 .
Color of both pasteurized and UHT milk was yellowish white. Flavour was satisfactory and tests results were very good except samples of company-1 (20). Titratable acidity is a measure of freshness and bacterial activity in milk (21). Less than $0.14 \%$ acidity percentage of pasteurized milk samples are given in the Table 4 and acidity range in Table 5 . The acidity range was between 0.14-0.16 (22).

SNF calculation is important to measure solids not fats (15). According to BDS standard, minimum SNF should be $8 \%$. SNF range of pasteurized milk was between $8 \%$ to $9.784 \%$ (Table 4) and SNF range of UHT milk was between the ranges of $8.034 \%$ to $9.012 \%$ (Table 5). To determine the SNF it is essential to detect CLR and Fat\%. The result was accurate according to BDS standard. Alcohol test is very important to determine the property of milk samples, alcohol is absent for all the pasteurized and UHT milk samples (table 4 and table 5).

Methylene Blue Dye Reduction Test is used to identify the bacterial range within the samples. Discoloration occurs within $1 / 2$ hour for samples of company-3, which indicates $>5$ million bacterial counts and the quality of this sample is very poor (Fig. 1). But for other milk sample discoloration didn't occur even after 5 hours, which indicates that bacterial load was $<0.2$ million and the quality of all the pasteurized milk samples are good except samples of company-3.
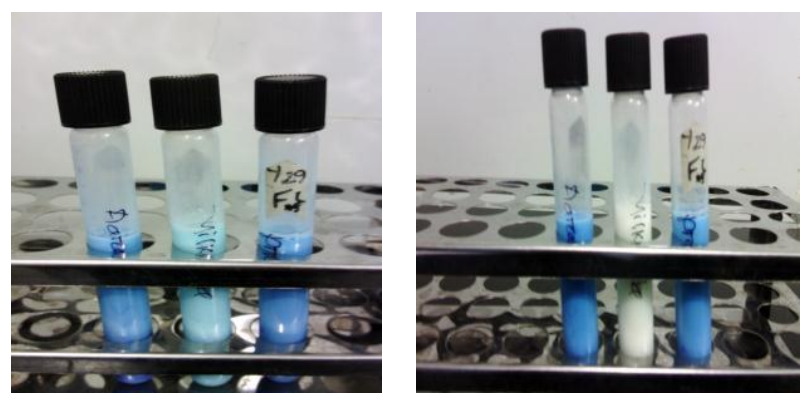

FIG 1. results of Methylene Blue Dye Reduction Test for pasteurized milk samples after $1 \frac{1}{2}$ hour (left) and after 2 hours (right).

\section{CONCLUSION}

From the present study, it can be concluded that the microbiological quality of most of the pasteurized milk samples collected from different areas of Dhaka city were not much satisfactory as indicated by their high bacterial loads though the range is under BDS standard and presence of coliform bacteria also detected for some milk samples, the range was also under BDS range. But presence of coliform always indicates the faecal contamination. In this case results were not satisfactory. But UHT milk samples and flavoured milk samples give satisfactory result. The physiochemical properties of all the milk samples were good but fat range is more for samples of company-1 than other milk samples. 
TABLE 4. Physiochemical test of pasteurized milk samples

\begin{tabular}{|c|c|c|c|c|c|c|c|c|c|c|}
\hline Brand name & $\begin{array}{c}\text { Serial } \\
\text { number }\end{array}$ & Color & Flavour & Taste & Alcohol & CLR & $\begin{array}{c}\text { Fat } \\
\%\end{array}$ & Acidity & pH & SNF\% \\
\hline \multirow{5}{*}{ Company-1 } & 1 & Yellowish white & $\mathrm{Ok}$ & Good & $-\mathrm{Ve}$ & 1.027 & 3.6 & 0.14 & 6.79 & 8.262 \\
\hline & 2 & Yellowish white & $\mathrm{Ok}$ & Good & $-\mathrm{Ve}$ & 1.029 & 3.8 & 0.14 & 6.75 & 8.806 \\
\hline & 3 & Yellowish white & Ok & Good & $-\mathrm{Ve}$ & 1.027 & 3.5 & 0.16 & 6.79 & 8 \\
\hline & 4 & Yellowish white & Ok & Good & $-\mathrm{Ve}$ & 1.029 & 3.6 & 0.14 & 6.68 & 8.762 \\
\hline & 5 & Yellowish white & $\mathrm{Ok}$ & Good & $-\mathrm{Ve}$ & 1.026 & 3.7 & 0.15 & 6.69 & 8.034 \\
\hline \multirow{5}{*}{ Company-2 } & 1 & Yellowish white & Ok & Very good & $-\mathrm{Ve}$ & 1.0315 & 3.7 & 0.15 & 6.75 & 9.284 \\
\hline & 2 & Yellowish white & Ok & Very good & $-\mathrm{Ve}$ & 1.033 & 3.7 & 0.16 & 6.65 & 9.784 \\
\hline & 3 & Yellowish white & Ok & Very good & $-\mathrm{Ve}$ & 1.0315 & 3.9 & 0.14 & 6.69 & 9.328 \\
\hline & 4 & Yellowish white & $\mathrm{Ok}$ & Very good & $-\mathrm{Ve}$ & 1.0315 & 3.5 & 0.15 & 6.75 & 9.24 \\
\hline & 5 & Yellowish white & Ok & Very good & $-\mathrm{Ve}$ & 1.0325 & 3.7 & 0.15 & 6.72 & 9.334 \\
\hline \multirow{5}{*}{ Company-3 } & 1 & Yellowish white & Ok & Very good & $-\mathrm{Ve}$ & 1.031 & 3.8 & 0.16 & 6.64 & 9.306 \\
\hline & 2 & Yellowish white & Ok & Very good & $-\mathrm{Ve}$ & 1.033 & 3.6 & 0.14 & 6.77 & 9.762 \\
\hline & 3 & Yellowish white & $\mathrm{Ok}$ & Very good & $-\mathrm{Ve}$ & 1.031 & 3.6 & 0.14 & 6.68 & 9.262 \\
\hline & 4 & Yellowish white & $\mathrm{Ok}$ & Very good & $-\mathrm{Ve}$ & 1.030 & 3.8 & 0.16 & 6.63 & 9.056 \\
\hline & 5 & Yellowish white & Ok & Very good & $-\mathrm{Ve}$ & 1.030 & 3.7 & 0.16 & 6.75 & 9.034 \\
\hline \multirow{5}{*}{ Company-4 } & 1 & Yellowish white & Ok & Very good & $-\mathrm{Ve}$ & 1.028 & 3.5 & 0.15 & 6.78 & 8.49 \\
\hline & 2 & Yellowish white & Ok & Very good & $-\mathrm{Ve}$ & 1.030 & 3.6 & 0.14 & 6.72 & 9.012 \\
\hline & 3 & Yellowish white & $\mathrm{Ok}$ & Very good & $-\mathrm{Ve}$ & 1.030 & 3.5 & 0.15 & 6.68 & 8.99 \\
\hline & 4 & Yellowish white & $\mathrm{Ok}$ & Very good & $-\mathrm{Ve}$ & 1.029 & 3.7 & 0.15 & 6.70 & 8.784 \\
\hline & 5 & Yellowish white & $\mathrm{Ok}$ & Very good & $-\mathrm{Ve}$ & 1.031 & 3.5 & 0.14 & 6.66 & 9.24 \\
\hline
\end{tabular}

TABLE 5. Physiochemical test of UHT milk Samples

\begin{tabular}{|c|c|c|c|c|c|c|c|c|c|c|}
\hline Brand name & $\begin{array}{c}\text { Serial } \\
\text { number }\end{array}$ & Color & Flavour & Taste & Alcohol & CLR & $\begin{array}{c}\text { Fat } \\
\%\end{array}$ & Acidity & pH & SNF \\
\hline \multirow{5}{*}{ Company-5 } & 1 & Yellowish white & $\mathrm{Ok}$ & Very good & $-\mathrm{Ve}$ & 1.027 & 3.6 & 0.16 & 6.6 & 8.262 \\
\hline & 2 & Yellowish white & Ok & Very good & $-\mathrm{Ve}$ & 1.029 & 3.5 & 0.16 & 6.4 & 8.99 \\
\hline & 3 & Yellowish white & $\mathrm{Ok}$ & Very good & $-\mathrm{Ve}$ & 1.029 & 3.6 & 0.16 & 6.3 & 9.012 \\
\hline & 4 & Yellowish white & Ok & Very good & $-\mathrm{Ve}$ & 1.028 & 3.6 & 0.14 & 6.6 & 8.512 \\
\hline & 5 & Yellowish white & $\mathrm{Ok}$ & Very good & $-\mathrm{Ve}$ & 1.027 & 3.5 & 0.14 & 6.4 & 8.25 \\
\hline \multirow{5}{*}{ Company-6 } & 1 & Yellowish white & Ok & Very good & $-\mathrm{Ve}$ & 1.026 & 3.7 & 0.15 & 6.8 & 8.034 \\
\hline & 2 & Yellowish white & $\mathrm{Ok}$ & Very good & $-\mathrm{Ve}$ & 1.027 & 3.8 & 0.15 & 6.8 & 8.306 \\
\hline & 3 & Yellowish white & $\mathrm{Ok}$ & Very good & $-\mathrm{Ve}$ & 1.027 & 3.7 & 0.13 & 6.7 & 8.284 \\
\hline & 4 & Yellowish white & OK & Very good & $-v e$ & 1.026 & 3.7 & 0.16 & 6.6 & 8.034 \\
\hline & 5 & Yellowish white & $\mathrm{OK}$ & Very good & -ve & 1.027 & 3.7 & 0.15 & 6.7 & 8.284 \\
\hline \multirow{5}{*}{ Company-7 } & 1 & Yellowish white & $\mathrm{Ok}$ & Very good & $-\mathrm{Ve}$ & 1.029 & 3.6 & 0.15 & 6.6 & 8.765 \\
\hline & 2 & Yellowish white & Ok & Very good & $-\mathrm{Ve}$ & 1.029 & 3.7 & 0.15 & 6.6 & 8.784 \\
\hline & 3 & Yellowish white & Ok & Very good & $-\mathrm{Ve}$ & 1.028 & 3.5 & 0.16 & 6.7 & 8.49 \\
\hline & 4 & Yellowish white & $\mathrm{Ok}$ & Very good & $-\mathrm{Ve}$ & 1.029 & 3.6 & 0.16 & 6.5 & 8.762 \\
\hline & 5 & Yellowish white & Ok & Very good & $-\mathrm{Ve}$ & 1.028 & 3.7 & 0.15 & 6.5 & 8.534 \\
\hline
\end{tabular}

\section{CONFLICTS OF INTERESTS}

Authors have no conflicts of interests

\section{ACKNOWLEDGEMENT}

Authors are thankful to the department of Microbiology, Stamford University Bangladesh for technical help.

\section{REFERENCES}

1. Aggad H, Bridja M, Aek B, Benaouali M, Djebli A. 2010. Some quality aspects of pasteurized milk in Algeria, World J. Dairy Food Sci. 5 (1): 2124

2. Haug A, Hostmark AT, Harstad OM. 2007. Bovine milk in human nutrition - A review. Lipids in Health and Disease. 6: 25.

3. Kohlbacher S. 2013. WA in a flavoured milk war. PerthNow.

4. Kim H, Hardy J, Novak G, Ramet JP, Weber F. 1983. Off-tastes in raw and reconstituted milk. FAO Animal Production and Health Paper. 35: 2.

5. Pelczar MJJR, Reid RD. 1991. Microbiology, $5^{\text {th }}$ ed. Tata Mcgraw Hill Publishing Company Ltd. Newvork.
6. Isha M, Michel N, Obed N, Philip KC. 2006. Hygienic milk production A training guide for farm-level workers and milk handlers in Eastern Africa. Module 1. Kenya.

7. Hossain TJ, Alam K, Sikdar D. 2010. Chemical and microbiological quality assessment of raw and processed liquid market milks of Bangladesh. Res. J. Dairy Sci. 4 (4); 28-34.

8. BSTI. 2002. Bangladesh Standard: Specification for Pasteurized Milk. Bangladesh Standards and Testing Institution, Tejgaon Industrial Area, Dhaka.

9. Uddin MA, Haque HMM, Noor R. 2011. Isolation and identification of pathogenic Escherichia coli, Klebsiella spp. and Staphylococcus spp. in raw milk samples collected from different areas of Dhaka City, Bangladesh. Stam. J. Microbiol. 1 (1): 19-23.

10. Banik SK, Das KK, Uddin MA. 2014. Microbiological quality analysis of raw, pasteurized, UHT milk samples collected from different locations in Bangladesh. Stam. J. Microbiology. 4 (1): 5-8.

11. Hassan A, Amjad I, Mahmood S. 2009 Microbiological and physicochemical analysis of different UHT milk available in a local market. As. J. Food Ag-Ind. 2 (3): 434-447.

12. Marshall RT. 1992 .Standard methods for the determination of dairy products. $16^{\text {th }}$ ed. Publ. American Public Health Association, USA.

13. AOAC. 2005. The association of official analytical chemists. $16^{\text {th }}$ ed. North Fredrick Avenue Gaithersburg, Maryland, USA

14. FAO. 1997. Milk testing and quality control. Milk Processing Guide Rome, Italy. $2: 2$. 
15. AOAC. 2005. Official methods of analysis. The association of official analytical chemists. 16th edition. 481. North Fredrick Avenue Gaithersburg, Maryland, USA

16. FAO. 1997. Milk testing and quality control. Milk processing guide. Rome, Italy.

17. Ramsey JA, Swartzel KR. 1984. Effect of UHT processing and storage conditions on rates of sedimentation and fat separation of aseptically packaged milk. J. Food Sci. 49: 257-262.

18. Jepras RI, Paul FE, Pearson SC, Wilkinson MJ. 1997. Rapid assessment of antibiotic effects on Escherichia coli by bis -(1, 3Dibutylbarbituric Acid) trimethine oxonol and flow cytometry. Antimicrob. Agents Chemother. 41: 2001-2005.

19. May JM, Qu Z, Whitesell RR. 2003. Generation of oxidant stress in cultured endothelial cells by methylene blue: protective effects of glucose and ascorbic acid. Biochem. Pharmacol. 66: 777-784.
20. Nandy SK, Venkatesh KV. 2008. Effect of Carbon and Nitrogen on the cannibalistic behavior of B. Subtilis . Appl. Biochem. Biotechnol. 151: 424432.

21. Shojaei ZA, Yadollahi A. 2008. Physiochemical and microbiological quality of raw, pasteurized and uht milks in Shops, As. J. Sci. Res. 1 (5): 532-538.

22. Larmond E. 1977. Laboratory methods of sensory evaluation of foods. Research Branch, Department of Agricultural Publication. Canada.

23. Popescu, A. and Angel E. 2009 Analysis of milk quality and its importance for milk processors. Lucrări Ştiinţifice Zootehnie Şi Biotehnologii. 42 (1): 501-503.

24. Elmagli AAO, El Zubeir EL. 2006. Study on the compositional quality of pasteurized milk in Khartoum State (Sudan). Int. J. Dairy Sci. 1 (1): 12-20. 